\title{
Aesthetic On The "Kaulinan" Of Sundanese, Kolecer
}

\author{
Sonson Nurusholih, Gandara Permana \\ Visual Communication Department \\ Faculty of Creative Industry - Telkom University \\ E-mail: sonson@telkomuniversity.ac.id, gandarap@telkomuniversity.ac.id
}

\begin{abstract}
Abstrak
Di Indonesia beragam permainan dengan latar budaya yang berbeda, mempunyai nilai dan makna yang terkandung dalam permainan atau mainan tersebut. Banyak makna terkandung dalam setiap permainan tradisional, namun tidak universal, melainkan terikat oleh budaya, setiap makna mempunyai nilai estetika yang berkaitan dengan sikap dan kebiasaan masyarakat tempat mainan itu berada. Demikian juga dengan permainan tradisional Sunda Kolecer, yang akan di jadikan objek penelitian. Dalam penelitian ini, penulis akan mempelajari estetika yang terdapat pada kaulinan Sunda Kolecer. Tujuan penelitian ini adalah untuk mengetahui makna kaulinan Sunda Kolecer. Adapun penelitian ini dilakukan dengan menggunakan metode deskriptif dengan pendekatan estetika paradoks. Hasil penelitian menemukan bahwa kolecer sebagai artefak dan kokoleceran sebagai mainan (kaulinan) masyarakat Sunda memiliki nilai filosofis dan nilai pendidikan.
\end{abstract}

Kata Kunci-Permainan Tradisional, Kaulinan Sunda, Kolecer

\begin{abstract}
In Indonesia, there are varieties of games with different cultural backgrounds, having value and meaning contained in the game or toy. Many meanings are contained in every traditional game bounded by culture not universally. Every meaning has an aesthetic value relating to the attitudes and habits of the people where the toys are located. Likewise with the traditional game of Sundanese Kolecer, which will be made as object of the research. In this research, the author will study the aesthetics contained in Kaulinan Sunda Kolecer. The purpose of this research is to know the meaning of Kaulinan Sunda Kolecer. The study was conducted by using descriptive method with a paradoxical aesthetic approach. The results of the study found that kolecer as an artefact and kokoleceran as toy (kaulinan) of Sundanese people which have philosophical and educational values.
\end{abstract}

Keywords-. Traditional Games, Kaulinan Sunda, Kolecer 


\section{INTRODUCTION}

Humans as homo lundes mean humans who play, therefore playing activities are the basic elements that always exist in the life of every human being. Toys as a means of human activities have developed in accordance with the changing times. Every nation in the world has a game that characterizes and identifies the nation itself. Similarly in Indonesia, as a rich country with various tribes with their own culture, traditional games can be found in almost all places in this country. In Indonesia a variety of games with different cultural backgrounds, have value and meaning contained in the game or toy. Many games are associated with identities, symbols, religious ceremonies, customs and toys are as parts of the character formation of the child.

One artifact that comes from the area of West Java and serves as a functional object and game found starting from Kuningan, Subang to Sumedang is kolecer. In the process, the first children played a kolecer made of midrib. Kokoleceran is a toy (cocoan) of children: artifacts in the form of small size made by children resemble a large colecer and its function as a toy only. How it works is to make it from the leaves of coconut trees and stick and to play it, just brought by running until the kolecer can spin.

The process of playing kolecer, a child will start the stages of learning by making a simple kolecer made of palm leaf material barred 2. The meaning of this 2 is to show that children exist because there is an ancestor who gave birth to us from 2 water, 2 respected human ancestor i.e. mother and father. Next is the manufacture of kolecer with bar 4. Making kolecer with bar 4 requires better skill. Stage 4 also likens life in adulthood about life which must be square (masagi) in Sundanese society. Last is the manufacture of kolecer with bar 8 which is the most difficult part in the process of making kolecer. Even so, the kolecer made from the crossbar 8 will produce beautiful shapes and rounds.

\section{RESEARCH METHOD}

This study used descriptive qualitative method. Qualitative descriptive method aims to describe the field and facts systematically and carefully. This topic is analyzed by visual content approach by dissecting the Kolecer's aesthetics, philosophy and the meaning values contained in the kaulinan

\subsection{Paradox Aestetics}

To study the 'aesthetics' of musical tradition used the antagonistic dualism theory from Jakob Sumardjo's findings. The theory of "antagonistic dualism" departs from the religious thinking of Sundanese mythical and other cultures in Indonesia. Based on the mythical spiritual-cultural thinking that all these "existences" always consist of two conflicting elements. Existence itself is related to "spiritual existence" and "material existence" or material. Both of them have different and conflicting characteristics (Sumardjo, 2003 :5)

The Sundanese (primordial) divides this "existence" into two categories: "The Upper World" and "The Underworld". Both are one unity for this life to continue to proceed. The marriage between "Upper World" and "Underworld" can give birth to "Middle-earth." The Upper and Lower Worlds are antagonistic. The Top World is female (wet), while the Underworld is male (dry). The unification of the "Upper World of Women" and the "Male Underworld" can produce a "Middle-earth" filled by all 
human beings, both male and female (Sumardjo, $2003: 6$ ).

To clarify the description, see the following quote. How can life continue to be nurtured? They try to marry opposing twin opposition pairs, but they are complementing each other. From marriage, a new life can emerge. Rice crops can continue to live if there is a 'marriage' between heaven and earth. The sky pours rain on dry ground. Thus, the sky is "wet" and "dry" earth. Wet is the principle of female and dry male principle. The marriage between the two will create the third entity, the life on earth. The sky is above, the earth is below, and life is appeared in the midst of heaven and earth. These three worlds are one unity that keeps this life (Sumardjo, 2006:72).

According to Sumardjo, unifying the sky (the upper world) and the earth (the underworld) can give birth to the middle world. This middle world is a universe inhabited by mankind. The marriage of these two paradoxes can give birth to a "third world" that gives birth to the concept of "pattern three." The way of thinking of the three patterned Sundanese people, such as can be proved through the arrangement of the house, the state setting, the weapon form cleaver, and the mythology of the Sundanese pantun. According to Jakob Sumardjo, "pattern three" is a way of thinking of the field community. The obsession of the field community is 'to live'. The basic belief of human cosmology of this farmer became the basis of his way of thinking for everything. The primordial community of the field believes that all existence is dualistic. However, the dualistic is a binary pair, i.e. two conflicting pairs. Sumardjo further states as follows: Pattern three departs from the two-lisme antagonistic belief of all things. For example, the sky above, the earth below; wet sky, dry earth; female sky, earth man; bright sky, dark earth. Both are separated and have distance. Partition is not good because it will bring death. The separation of all things antagonistic dualistic must be terminated, that is, by allowing both of them. Life is possible because of harmony. The requirement of life is the harmony of two conflicting but complementary entities (Sumardjo, 2006:73).

The concept of "pattern three" which is the basis of thinking of this field society will be used as a theoretical base to study of 'aesthetics' so that it is expected to produce 'aesthetics' kaulinan Sundanese tradition that has not been revealed.

\subsection{RESULTS AND DISCUSSION}

Kolecer in Sundanese society is quite important role, played from childhood to adulthood. Toys or kaulinan is not only more than as a mean of recreation but also it has the meaning or value contained in this object.

In addition, one of the functions of the kolecer made is a recreational element in the form of sound produced from its movement caused by the wind. The sound of "wuuk ... wuuuk .." produced became the pride of the owner. In general the shape or archetype of this kolecer is a triangle consisting of the main part of the jajabing-rarawis.

The meaning of rounds on a bamboomade kolecer implies the symbol of life in Panca Buana Tengah and the vertical round is the life of Buana Nyungcung or the Upper world. It is interpreted as respect and devotion to the belief of the Sundanese people that the rice is a marriage between Nyi Pohaci with the earth. And if anyone has a field but it does not install a kolecer, then it is believed will fall ill. 


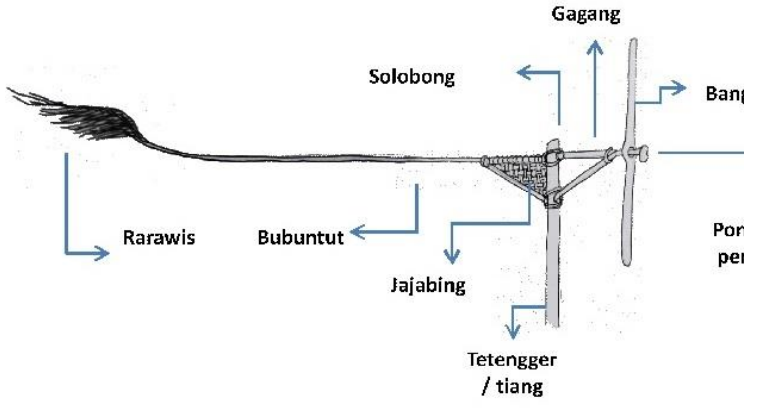

Figure 1. Kolecer

(Source : Nurusholih, 2015)

The names of Kolecer parts and their functions are as follows:

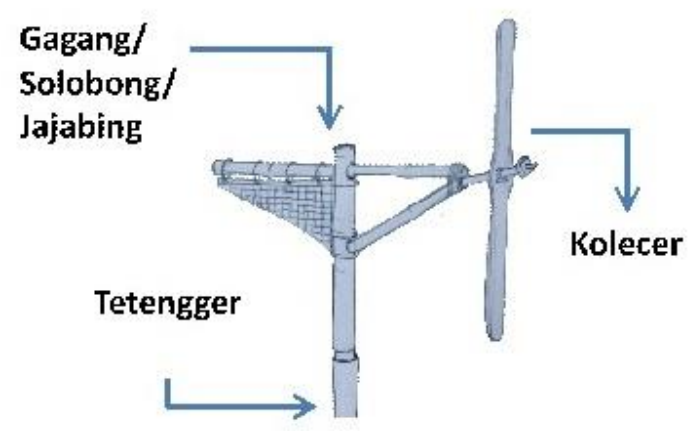

Figure 2. Kolecer

(Source : Nurusholih, 2015)

3 main parts of the kolecer are: Tetengger / pole: the bamboo part of a pole tied with the bonds of some bamboo. Jajabing: serves to rotate the collecher. Solobong: the bamboo part that is connected with the shaft. If you note the 3 main parts kolecer the pole (tetengger) and then jajabing and solobong are very closely related, if one does not work, then kolecer will not spin. 3 part is like Sundanese philosophy related to tritangtu Sunda, Tekad, ucap and lampah, or silih asuh asih dan silih asah.
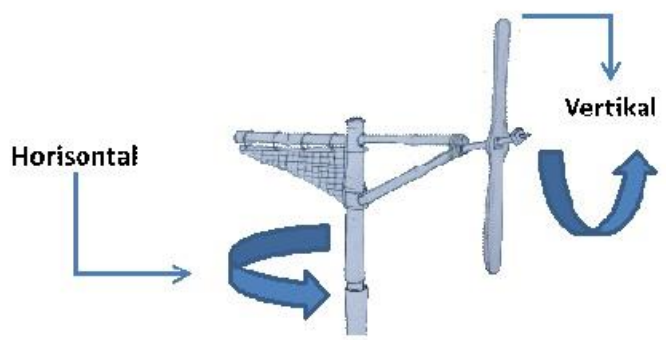

Figure 3. Kolecer

(Source : Nurusholih, 2015)

The pole and handle relationships are inseparable, both in pairs. The pole becomes the foundation of the Kolecer and the handle connects with the propeller. The handle will spin horizontally along the direction of the wind, and the propeller will rotate vertically when the wind blows.

The rotation of the propeller at the kolecer implies the division of the universe in the Sundanese society that is the first round horizontally as the symbol of life in Buana Panca Tengah, and the vertical round is the life of Buana Nyungcung or Upper world.

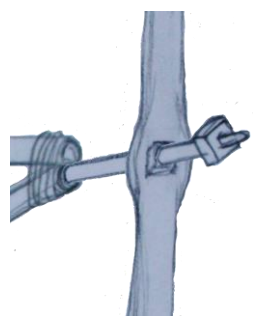

Figure 4. Bangbrang/pongpok

Bangbrang / Pongpok: The shaft is made of bamboo as well as the part to lock the propeller. It implies that man must lock his life wheel in order not to stray.

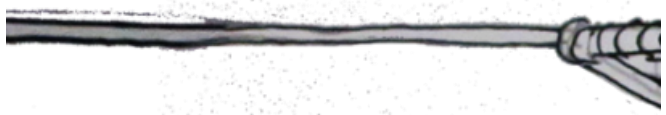

Figure 5. Buntut

Bubuntut: The back, serves as a counterweight and adjusts the direction of 
the propeller. The meaning is that a man must be able to balance his life.

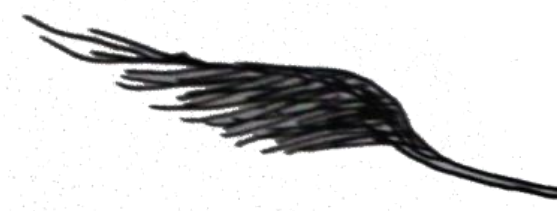

Figure 6. Rarawis

Rarawis: Ornaments made from ijuk. It has the meaning that part of our life is always decorated with worldly things

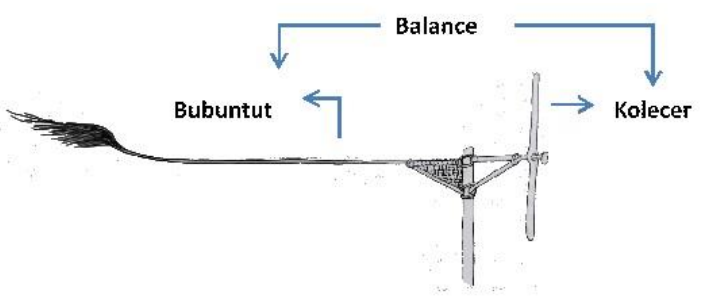

Figure 7. Kolecer

Kolecer forms have a long tail. Ergonomically, because part of the kolecer itself is quite heavy then to make balance, it needs a long tail so kolecer is not curved. In Sundanese society, the above equilibrium means "mun kudu sarua jeung eusina" or if a container must be equal to its contents. The meaning of this sentence is very depth depending on the context, for example honesty, if a container contains 4 objects, then we must call it 4 and it should not be 3 or other numbers because it is same as lying.

To make this kolecer work, it needs a great wind to rotate the axis of the kolecer so as to cause a loud noise from the rotating blades. The faster the rotation of the blades, the louder the sound of the blades will be, the values contained in the kolecer are greater on the cosmological contexts of the Sundanese then the parts of Kolecer namely Tetengger, Solobong and
Bubuntut which have the meaning of rotation of the propeller on the kolecer implies the division of the universe in the Sundanese society that is the first round horizontally is the symbol of life in Buana Panca Tengah, and the vertical round is the life of Buana Nyungcung or Upper world.

Among the three, Pongpok which means that humans can lock the wheel of life so as not to deviated. Another important part of Kolecer is Bubuntut or tail that means how humans control the way of life. And last part of the Kolecer called Jajabig has the notion that the part of our lifes is decorated with worldliness.

Indirectly, the relationship between children who make kokoleceran to adult make kolecer is a stage that must be passed by a person in his life sequentially, starting from the easy thing, then must masagi first before to stage eight which is the stage where a child who has grown, has already had the readiness and power in navigating his life.

\section{CONCLUSION}

Kolecer as an artifact and Kokoleceran as toys (kaulinan) Sundanese people are very closely related because it has a philosophical value and there are meanings contained in it. Kaulinan Sunda, in addition beside it has many benefits, it has a very educational philosophical values. The game of tradition is also one form of cultural endurance.

Variety of traditional games can be seen from the geographical location of the community. Sundanese who live in the fields, have a different game with the Javanese living in the area of paddy fields. So the traditional game will be closely 
related to the cultural order in which the game is located.

The game of the people can function to take the heart (placate), which all the functions were then squeezed into one, said by R.E Herron and B. SuttonSmith is called as a function to prepare children to participate in adult life.

In association with Kolecer, in making Kokoleceran, children are required to be able to make these toys independently, who can make Kolecer until it can spin and sound means that he has been able to make it. In the future when the child grows up, the meaning of learning makes Kolecer which will be used in the form of ability in work later. Based on the description, it can be seen that the game is played more leading to the measurement of self-ability and as indirect learning of children for the future.

[1] Danandjaja, James. 1982. Folklor Indonesia. Jakarta: Grafitripers.

[2] Sumardjo, Jakob. 2014. Estetika Paradoks. Bandung: Kelir

[3] Suryani NS, Elis . 2011. Ragam Pesona Budaya Sunda. Bogor: Ghalia Indonesia

[4] Rohendi, Tjejep. 2011.Metodologi Penelitian Seni.Cipta Prima Nusantara.Semarang.

Sachari, Agus.2007. Budaya Visual Indonesia.Erlangga. Jakarta. 